\title{
Advances in Transgenic Vegetable and Fruit Breeding
}

\author{
João Silva Dias ${ }^{1}$, Rodomiro Ortiz ${ }^{2}$ \\ ${ }^{1}$ University of Lisbon, Instituto Superior de Agronomia, Lisboa, Portugal \\ ${ }^{2}$ Swedish University of Agricultural Sciences, Alnarp, Sweden \\ Email: mirjsd@gmail.com
}

Received 5 November 2014; revised 20 November 2014; accepted 2 December 2014

Copyright (C) 2014 by authors and Scientific Research Publishing Inc.

This work is licensed under the Creative Commons Attribution International License (CC BY). http://creativecommons.org/licenses/by/4.0/

(c) (i) Open Access

\section{Abstract}

Vegetables and fruits are grown worldwide and play an important role in human diets because they provide vitamins, minerals, dietary fiber, and phytochemicals. Vegetables and fruits are also associated with improvement of gastrointestinal health, good vision, and reduced risk of heart disease, stroke, chronic diseases such as diabetes, and some forms of cancer. Vegetable and fruit production suffers from many biotic stresses caused by pathogens, pests, and weeds and requires high amounts of plant protection products per hectare. United States vegetables farmers are benefiting from growing transgenic squash cultivars resistant to Zucchini yellow mosaic virus, Watermelon mosaic virus, and Cucumber mosaic virus, which were deregulated and commercialized since 1996. Bt-sweet corn has also proven effective for control of some lepidopteran species and continues to be accepted in the fresh market in the USA, and Bt-fresh-market sweet corn hybrids are released almost every year. Likewise, transgenic $B t$-eggplant bred to reduce pesticide use is now grown by farmers in Bangladesh. Transgenic papaya cultivars carrying the coat-protein gene provide effective protection against Papaya ring spot virus elsewhere. The transgenic "Honey Sweet" plum cultivar provides an interesting germplasm source for Plum pox virus control. Enhanced host plant resistance to Xanthomonas campestris pv. musacearum, which causes the devastating banana Xanthomonas wilt in the Great Lakes Region of Africa, was achieved by plant genetic engineering. There are other vegetable and fruit crops in the pipeline that have been genetically modified to enhance their host plant resistance to insects and plant pathogens, to show herbicide tolerance, and to improve features such as slow ripening that extends the shelf-life of the produce. Consumers could benefit further from eating more nutritious transgenic vegetables and fruits. Transgenic plant breeding therefore provides genetically enhanced seed embedded technology that contributes to integrated pest management in horticulture by reducing pesticide sprays as well as improving food safety by minimizing pesticide residues. Furthermore, herbicide-tolerant transgenic crops can help reducing plough in fields, thereby saving fuel because of less tractor use, which also protects the structure of the soil by reducing its erosion. Transgenic vegetable and fruit crops could make important contributions to sustainable vegetable production and for more nu- 
tritious and healthy food. Countries vary, however, in their market standards of acceptance of transgenic crops. Biotechnology products will be successful if clear advantages and safety are demonstrated to both growers and consumers.

\title{
Keywords
}

\author{
Biosafety, Fruits, GM-Crops, GMO, Health Benefits, IPM, Market, Nutrition, Plant Breeding, \\ Sustainability, Vegetables
}

\section{Introduction}

Vegetables and fruits are grown worldwide and make up a major portion of the diet of humans in many parts of the world. They play a significant role in human nutrition, especially as sources of vitamins (C, A, B1, B6, B9, E), minerals, dietary fiber and phytochemicals [1]. Vegetables and fruits in the daily diet have been strongly associated with improvement of gastrointestinal health, good vision, and reduced risk of heart disease, stroke, chronic diseases such as diabetes, and some forms of cancer [2].

Vegetable and fruit consumption worldwide is rising, reflecting the consumer's increased income, desire of diversity, and awareness of nutritional benefits. A world vegetable survey showed that 402 vegetable crops are cultivated worldwide, representing 69 families and 230 genera [3] [4]. Leafy vegetables—of which the leaves or young leafy shoots are consumed - were the most often utilized (53\% of the total), followed by vegetable fruits (15\%), and vegetables with below ground edible organs comprised $17 \%$. Many vegetable crops have more than one part used. Most of the vegetables are marketed fresh with only a small proportion processed because most vegetables are perishable. Consumption shortly after harvest guarantees optimal vegetable quality.

Vegetable and fruit production, due to their cultivation intensity, suffers from many biotic stresses caused by pathogens, pests, and weeds and requires high amounts of pesticides per hectare. Because of the high diversity of vegetable crops, pest loads vary and are complex vis-à-vis field crops. The main method for controlling pathogens, pests, and weeds has been the use of pesticides because vegetables and fruits are high-value commodities with high cosmetic standards. Synthetic pesticides have been applied to vegetable crops since the 1950s, and have been highly successful in reducing crop losses to some insects, other pathogens, and weeds. Vegetables account for a significant share of the global pesticide market. About $20 \%$ of the world's annual pesticides expenditures (amounting to US $\$ 8.1$ billion) are spent for growing vegetables [5]. Only cotton used more insecticides than vegetables on an area basis. Insecticides are regularly applied to control a complex of insect pests that cause damage by feeding directly on the plant or by transmitting pathogens, particularly viruses. Despite pesticide use, insects, pathogens, and weeds continue to cause a heavy toll on world vegetable production. Preharvest losses are globally estimated as $15 \%$ for insect pests, $13 \%$ for damage by pathogens, and about $12 \%$ for weeds [6]. Pesticide residues can affect the health of growers and consumers and contaminate the environment. Vegetables are often consumed in fresh form, so pesticide residue and biological contamination is a serious issue. Consumers worldwide are increasingly concerned about the quality and safety of their food, as well as the social and the environmental conditions under which it is produced. Vegetable prices will therefore increase by enhancing their quality and safety [1].

Transgenic crops, commonly referred to as genetically modified (GM), crops enable breeders to bring favorable genes, often previously inaccessible, into already elite cultivars, improving their value considerably and offer unique opportunities for controlling insects and other pathogens. Many vegetable and fruit crops have been genetically modified to include resistance to insects, other pathogens (including viruses), and herbicides and for improved features, such as slow ripening, higher nutritional status, seedless fruit, and increased sweetness. Recently, Dias and Ortiz [7] did a review (based on 372 articles) about the status of transgenic vegetables to improve their production. They analyzed the advances and potentials in transgenic research until 2010 on tomato, eggplant, potato, cucurbits, brassicas, lettuce, alliums, sweet corn, cowpea, cassava, sweet potato, and carrots. Some experimental transgenic vegetables show host plant resistance to insects, nematodes, fungi, bacteria, and viruses, extended shelf-life of the produce, herbicide tolerance, enhanced nutritional status, and seedless fruit and better flavor. Host plant resistance or product quality will increase the value of the vegetable throughout the chain, thereby benefiting farmers, traders and consumers. The most promising traits to reach vegetable and fruit 
growers seem to be host plant resistances to insects and other pathogens, especially for tomato, potato, eggplant, summer squash, sweet corn, papaya, plum and banana.

Breeding transgenic pest resistant and herbicide tolerant vegetable cultivars can decrease management costs and release growers' time for other economic activities, while also contributing to a less toxic production environment. Transgenic vegetables with tolerance to abiotic stresses or enhanced input efficiency could also provide various benefits to farmers and the environment, e.g. Bt cry genes could provide eggplants with host plant resistance to shoot borer while reducing today's insecticide spraying during the crop season: 40 to 80 times in India or 50 times in the Philippines [8] [9]. Consumers could also benefit further from the use of more nutritious transgenic vegetables, e.g. an increase of crop carotenoids by metabolic sink manipulation through a transgenic breeding approach appears feasible in some vegetable crops [7]. Genetically engineering carrots containing increased calcium (Ca) levels may boost Ca uptake, thereby reducing the incidence of Ca deficiencies such as osteoporosis. Fortified transgenic lettuce with zinc will overcome its deficiency that severely impairs organ function. Transgenic lettuce with improve tocopherol, and resveratrol composition may prevent coronary disease and arteriosclerosis and can contribute to cancer chemo preventative activity. Folates deficiency, which is regarded as a global health problem, can also be overcome with transgenic tomatoes with folate levels that provide a complete adult daily requirement [7]. Likewise, food safety can be enhanced through transgenic approaches, e.g. resource-poor people in rural Africa will benefit eating cyanide-free cultivars of cassava—a main staple in their diets [10]-[12].

Genetic engineering has the potential to address some of the most challenging biotic constraints faced by vegetables and fruit growers, which are not easily addressed through conventional plant breeding alone. However, horticulture remains in its infancy regarding the use of transgenic crop technology because vegetables are considered minor crops (compared to field crops), due to the lower resources invested (especially by the multinational private seed corporations), and derived of the high costs for deregulation [1]. Most biotech research is done in field crops because multinational seed corporations expect the highest rate of return to their investment. While it is becoming less expensive to create transgenic crops for pest management, developing a marketable product and a regulatory package remains costly. Development and regulatory costs can be recouped more readily if the product is grown on an extensive area (as happens with field crops), which is not generally the case for individual vegetable crops. The large multinational seed corporations have, for the most part, abandoned the development of transgenic vegetable and fruit crops because of the high costs associated with product development and deregulation [1] [7].

There are many cultivars of the same vegetable or fruit crop, and their expected life can be relatively short. Moreover, introducing a transgene into a breeding program can be complicated and cost prohibitive, especially in crops with difficulty for using backcrossing (e.g. banana, cassava, potato or sweet potato). Furthermore, deregulation of a transgenic trait is event specific in many countries. It may not be therefore possible to develop a single transgenic event that can be converted into many different cultivars of a single or closely related group of vegetable and fruit species through conventional breeding. This article highlights advances in breeding transgenic vegetables and fruits, and issues affecting their use, as illustrated by the case studies of tomato, potato, eggplant, squash, sweet corn, papaya, plum and banana and by the contribution of transgenic vegetables and fruits to more nutritious and healthy food.

\section{Advances in Breeding Transgenic Vegetables and Fruits: Case Studies}

\subsection{Tomato: Delaying Fruit Ripening}

The first commercially grown transgenic crop was Flavr Savr ${ }^{\mathrm{TM}}$ tomato, which was released by Calgene in 1994. This tomato contains an antisense version of the polygalacturonase $(P G)$ gene. The use of this gene ensued after many years of research on several genes involved in fruit development and tomato ripening. They were identified, cloned, and characterized to breed transgenic tomato cultivars [13]. However, Flavr Savr ${ }^{\mathrm{TM}}$ tomato failed in the market since this cultivar was considered inferior by growers, and was rapidly withdrawn from the market. Plant genetic engineers learned an important lesson after this failure: the importance of cooperation with plant breeders.

There has been further research conducted to manipulate fruit ripening, texture and nutritional quality using transgenic approaches. Many of the genes targeted include ethylene because of its role in fruit ripening [7]. Enzymes that regulate ethylene biosynthesis in plants are: S-adenosylmethionine (SAM) synthase, 1-aminocyclo- 
propane-1-carboxylate (ACC) synthase, and ACC oxidase. The genes encoding these enzymes [14] [15], as well as those that metabolize SAM or ACC [16] [17], have been targeted in order to manipulate ethylene biosynthesis, thereby regulating fruit ripening. It has been clearly shown that modulation of ethylene biosynthesis using genetic engineering can yield tomato fruits with predictable ripening characteristics. Tomato fruit ripening manipulation has been however achieved by introducing anti-ripening genes (rin and nor) in heterozygous genotypes. These genes have been incorporated in many fresh and processing tomatoes [7].

\subsection{Potato: Host Plant Resistance to Insects and Viruses}

After the first Bt-tomato was reported with partial resistance to lepidopteran insects, improvement through truncation of the $B t$ gene and codon modification were made to optimize protein expression in plants, and $B t$ potatoes expressing cry $3 A$ gene were developed. Bt-potato cultivars expressing resistance to Colorado potato beetle (Leptinotarsa decemlineata), the most destructive insect pest of potato in North America, and aphids associated with Potato virus Y and Potato leafroll virus, were approved for sale in the United States in 1995. The reported profits in USA were on average US \$55 ha ${ }^{-1}$ for Bt-potato [18]. Likewise, an ex-ante assessment of Monsanto’s

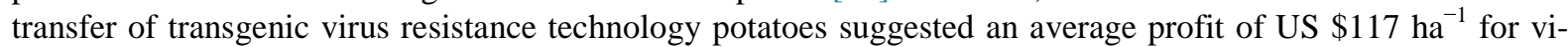
rus-resistant potato in Mexico [19]. Potato growers, either small or large, can benefit from this transgenic potato, as well as consumers because of the lower prices as a result of higher production.

New Leaf ${ }^{\circledR}$, New Leaf $\mathrm{Y}^{\circledR}$, and New Leaf Plus ${ }^{\circledR}$ were the trade names of the transgenic potato cultivars sold by Nature Mark ${ }^{\circledR}$, a subsidiary of Monsanto ${ }^{\circledR}$ [20]. About 600 ha were grown commercially in the United States when New Leaf ${ }^{\circledR}$ cultivars were introduced in 1995, and the commercial acreage further reached about 20,000 ha. Market success of the New Leaf ${ }^{\circledR}$, New Leaf $\mathrm{Y}^{\circledR}$, and New Leaf Plus ${ }^{\circledR}$ potatoes could be attributed to the difficulty in controlling Colorado potato beetle and also high pest populations of aphids and associated virus problems due to mild winters in the Pacific Northwest [21]. This virus resistance benefited seed producers, while commercial growers benefited from higher yields and reduced need for insecticides [21]. The processing industry and consumers benefited from improved quality. Potatoes were one of the first foods from a transgenic crop that was commonly served in restaurants. New Leaf ${ }^{\circledR}$ potato cultivars were the fastest cultivar adoption in the history of the USA potato industry [21], until potato processors, concerned about anti-biotech organizations, consumer resistance and loss of market share in Europe and Japan, suspended contracts for Bt-potatoes with growers in 2000 and they were taken off the market [22]. The crop area of transgenic insect and virus resistant potatoes did not increase at the same rate as happened in transgenic maize or transgenic cotton, irrespective of being highly effective and growers increasingly using them. The ability of growers to save potato tubers for future plantings, the registration of imidacloprid, a new insecticide that gave excellent control in the same year that $B t$-potato became available to growers, the request by consumers to segregate transgenic potatoes, and trade issues driven by international consumers could explain why the market growth for transgenic potatoes was not as rapid as the owners of the proprietary transgenic technology would have liked [21] [22]. International trade barriers were more substantial for transgenic potato than other technology adoptions [23], which further led to discontinuing its use by the processor and commercial grower, hence the loss of a market for Nature Mark ${ }^{\circledR}$ potatoes. An additional factor that also account for this rapid demise was that Bt-cultivars were only grown in $3 \%$ of the USA potato area [23]. The major impact came when the leading fast food McDonald's chain decided to ban transgenic potatoes from its servings. Nature Mark ${ }^{\circledR}$ dissolved after the 2001 season. This initial failure of transgenic potatoes shows that consumer acceptance should be regarded as key for adopting transgenic crop technology. Guenthner [23] indicated that although growers accepted transgenic potatoes, the processors had little to gain by accepting transgenic raw materials but exposed themselves to significant risk in marketing because they did not have a "consumer-acceptance accelerator".

The larvae of potato tuber moth (PTM, Phthorimaea operculella), the most common and destructive insect pest for this crop in tropical and sub-tropical areas worldwide [24] [25], mine the foliage, stems, and tubers in the field and also in storage, which leads to significant yield losses. Combining natural resistance mechanisms with Bt cry genes could be a potential solution to improve potato resistance to PTM [7]. Field and storage trials in Egypt, under natural infestation, revealed that Bt-cry5 transgenic potatoes derived from the cv. "Spunta" (“Spunta-G2”, “Spunta-G3”, and “Spunta-6a3”) had the highest host plant resistance to PTM, with almost 100\% of their tubers showing no insect damage in the field, and about 90\% free of insect damage after 3-month storage [26]. South Africa was selected as the target country for releasing and marketing transgenic PTM-resistance potato for small holder farmers because of its previous in-country experience with genetically modified potato research 
[27] [28]. Multi-location yield trials and PTM efficacy trials (field and storage) have been conducted at six locations in South Africa since 2001. Complete control of the PTM was found at all locations in all years, and there was no infestation in the field when examining the foliage and tubers of "Spunta-G2" and no infestation was found in tubers stored up to 6 months. The cry1Ia1 transgene was used to transform two popular South African potato cultivars to ensure a greater impact [7]. Further research by Cooper et al. [29] shows that expression of avidin combined with natural host plant resistance (from S. chacoense) in transgenic potato could be also useful for controlling PTM.

Specific issues need to be addressed for the potential use of transgenic potatoes in the center of origin of this crop: The Andean region. Celis et al. [30] assessed therefore the biosafety of transgenic potato in South America. They did not observe any harm in many non-target organisms but found that gene flow occurs to wild relatives growing near potato crops, which suggest that the fitness of these wild species could be altered if stable transgene introgression occurs. In this regard, Scurrah et al. [31] suggest the use of sterile cultivars with scarce flower production and lacking seed production to minimize the risk of gene flow from transgenic potato to wild relatives or native cultivars.

\subsection{Eggplant: Resistance to Fruit and Shoot Borer}

Eggplant is attacked by a number of insects including thrips, cotton leafhopper, jassids and aphids. The most damaging pest is the eggplant fruit and shoot borer (FSB, Leucinodes orbonalis). Losses have been estimated to be between 54\% and 70\% in India and Bangladesh and up to 50\% in the Philippines [9]. There are no known eggplant cultivars resistant to the fruit and shoot borer, so the use of insecticide sprays continues to be the most common control method used by growers. The borer is vulnerable to sprays only for a few hours before they bore into the plant, which explains why growers often spray every other day, particularly during the fruiting stage that contributes to the presence of pesticide residues.

FSB-resistant Bt-eggplant was genetically engineered by Mahyco under a collaborative agreement with Monsanto $^{\circledR}$ and the first Bt-eggplant with resistance to FSB was produced in 2000. This transgenic eggplant incorporates the cry $1 A c$ gene expressing insecticidal protein to confer resistance against FSB. This Bt-eggplant was effective against FSB, with 98\% insect mortality in Bt-eggplant shoots and 100\% in fruits compared to less than 30\% mortality in non-Bt counterparts [32]. Krishna and Qaim [33] indicated that simulations using farm-survey data suggest the aggregate economic surplus gains of Bt-eggplant hybrids could be around US\$ 108 million per year in India. Eggplant consumers will capture a large share of these gains, but farmers and the seed company will also benefit. By sharing this technology with the public sector, Bt-open-pollinated eggplant cultivars may become available with a certain time lag [34] [35], thereby making this technology more accessible for resourcepoor farmers.

An expert committee was setup in India to examine biosafety issues and data regarding Bt-eggplant in 2006 [9]. They initially indicated that Bt-eggplant was safe and equivalent to its non Bt-counterpart but more research and trials were still needed to confirm these findings and ascertain its benefits regarding existing methods for pest management and for reducing pesticide use. In 2009 a second expert committee examined the data from these new trials and concluded that benefits of the available Bt-eggplant outweighed the perceived and projected risks, thereby advising the Genetic Engineering Appraisal Committee (GEAC) to recommend its commercialization in India [36]. The GEAC cleared Bt-eggplant for commercialization in October 2009 but the Government of India officially announced in February 2010 that more time was needed before its release to farmers due to the successful lobbying made by anti-transgenic crop activists [37]. The Minister of Environment stated that this moratorium for growing Bt-eggplant in India will remain until reaching a political, scientific and societal consensus [38]. Recently in Bangladesh four cultivars of Bt-eggplant for control of eggplant FSB were deregulated and released commercially on October 2013, in order to reduce pesticide use, decrease cost of cultivation and increase marketable yield [39].

\subsection{Summer Squash: Multiple Virus Resistance}

Viruses cause $20 \%$ to $80 \%$ of yield losses in summer squash in the United States [40]. Three of the most important viruses affecting squash production are Zucchini yellow mosaic virus (ZYMV), Watermelon mosaic virus (WMV), and Cucumber mosaic virus (CMV). Summer squash cultivars with satisfactory resistance to CMV, ZYMV, and WMV are yet to become available from cross breeding [41]. Two lines of squash expressing the 
coat protein $(C P)$ gene of ZYMV, WMV and CMV were deregulated and commercialized in the United States in 1996. Subsequently, many squash types and cultivars have been bred, using crosses and backcrosses with the two initially deregulated lines. This material is highly resistant to infection by one, two or all three of the target viruses [42]-[47]. Virus-resistant transgenic squash limits virus infection rates by restricting challenge viruses, reducing their titers, or inhibiting their replication or cell-to-cell or systemic movement. Therefore, lower virus levels reduce the frequency of acquisition by vectors and subsequent transmission within and between fields. Consequently, virus epidemics are substantially limited. The adoption of virus resistant squash cultivars has steadily increased in the United States since 1996. This adoption rate was estimated at 12\% (approximately 3100 ha) across the country in 2005 [48]. Virus-resistant transgenic squash has allowed growers to achieve yields comparable to those obtained in the absence of viruses with a net benefit of US \$22 million in 2005 [48]. Nowadays United State farmers are benefiting from growing transgenic squash cultivars. Engineered resistance has been so far the only approach to breed squash cultivars with multiple sources of resistance to CMV, ZYMV, and WMV.

\subsection{Sweet Corn: From Bt to Triple "Stack" Transgenic Cultivars}

Sweet corn, expressing cry $1 A b$ endotoxin, was introduced commercially in the United States in 1998 into an industry that is highly sensitive to damage to corn ears from lepidopteran pests [49]. This endotoxin was very effective against the European corn borer (Ostrinia nubilalis) in the state of New York, providing $100 \%$ clean ears when no other lepidopteran species were present and in excess of $97 \%$ when the two noctuids, corn earworm (Helicoverpa zea) and fall armyworm (Spodoptera frugiperda), were also present [50]. Studies in other USA states have shown that Bt-sweet corn provided consistently excellent control of the lepidopteran pest complex and the potential for 70\% to 90\% reductions in insecticide requirement [49]-[54]. About 5\% of the 262,196 ha of sweet corn (fresh and processing) grown in the United States in 2006 was with Bt-sweet because corn processors have avoided growing Bt-sweet corn due to concerns about export markets [55]. It has been grown since then only as a fresh market vegetable crop.

An economic assessment in Virginia found a gain of US $\$ 1777 \mathrm{ha}^{-1}$ for fresh-market sweet corn vs. non$B t$-sweet corn sprayed up to six times with pyrethroid insecticides [53]. Bt-sweet corn was also much better at preserving major predators of $O$. nubilalis while controlling the European corn borer than were the commonly used insecticides lambda-cyhalothrin, indoxacarb and spinosad. Bt-sweet corn hybrids can be therefore truly integrated into a biological pest control program.

Monsanto $^{\circledR}$ announced recently the release, through its vegetable seed brand Seminis ${ }^{\circledR}$, of a "triple-stack" transgenic sweet corn with host plant resistance to insects, which also tolerates glyphosate sprays for weed control [56]. They expect that this transgenic sweet corn provides protection against damage by European corn borers, corn earworms, fall army worms and corn rootworm larvae, and reduces insecticide sprays up to $85 \%$ visà-vis. a non-transgenic sweet corn [57]. This transgenic sweet corn had below $3 \%$ ear damage by fall armyworm or earworm in trials [58]. The use by farmers of this insect-resistant sweet corn that tolerates glyphosate can also result in eco-efficiency because of less tractor trips across the field that help farmers to save fuel, thereby reducing greenhouse gas emissions and decreasing the carbon footprint per ear of corn grown.

\subsection{Papaya: Pathogen-Derived Resistance Save the Crop in Hawaii}

Papaya ringspot virus (PRSV) reduces both fruit quality and edible yield. Transgenic papaya with pathogenderived resistance carrying the coat-protein gene provides effective protection against PRSV strains over a significant period of the cycle of this perennial fruit crop [59]. Seeds of the transgenic cultivars "SunUp" and "Rainbow" became available to Hawaii's farmers in 1998, and growing cultivar "Raibow" led to a significant increase in papaya production [60]. Prior to the introduction of PRSV-resistant transgenic papaya, growing papaya in Hawaii was no longer viable despite area-wide efforts to erradicate infected trees in order to limit the propagation of the virus. The cultivation of PRSV-resistant transgenic papaya cultivars dramatically reduced the incidence of PRSV in many areas allowing some growers to return to growing non-transgenic papaya, which is important for the high value Japanese market in which transgenic papaya is not allowed. Growers have been able to use the PRSV-resistant transgenic papaya cultivars as a trap crop [61] by growing it as a border around the non-transgenic crop and allowing it to cleanse viruliferous aphids of PRSV [62]. Thus, the Hawaian papaya industry can now produce and market both transgenic and conventional papaya in the same field. The draft ge- 
nome of the cultivar "Sun Up" makes this papaya cultivar the best-characterized transgenic crop [63], which may assist to overcome regulatory barriers.

\subsection{Plum: Resistance to Plum Pox Virus}

There are few sources of natural resistance to Plum pox virus (PPV), the causative agent of Sharka, one of the worldwide most destructive diseases of plum and other stone fruits. Over the past 20 years an intensive international research project between USA, France, Poland, Romania, Spain, and Czech Republic has focused on the development of transgenic resistance to PPV [64]. The PPV coat protein (CP) gene was isolated, sequenced, and cloned by Ravelonandro et al. [65] and was used for Agrobacterium-mediated transformation of plum. This gene was transferred to plum through genetic engineering. As a result, the highly PPV-resistant cultivar "Honey Sweet" plum was bred. This cultivar has shown its host plant resistance after 15 years of field testing in Europe under heavy infection pressure [66]-[68] and in greenhouse tests in the USA (since field inoculations were not allowed because PPV was not in this country until 1999, and is still a quarantine organism under a containment and eradication program). Its transgenic resistance was further transferred to other seedlings through crossbreeding [69] [70], thus developing additional PPV-resistant cultivars. The efficacy and safety of "Honey Sweet" was assessed through laboratory, greenhouse and field research during 12 years, which led to the regulatory approval of this PPV resistant transgenic plum cultivar in the USA in 2011. "Honey Sweet" is the culmination of years of research and development. In anticipation of the potential spread of PPV to other US regions, breeding with "Honey Sweet" is underway to transfer the PPV resistance transgene into new cultivars adapted to different US growing locations. Breeding with "Honey Sweet” is relatively rapid since an easy molecular marker assay provides means for detecting its resistance transgene in "Honey Sweet" derived-seedlings. This resistance is transferred to the offspring as a single dominant gene. The transgene resistance technology and post-transcriptional gene silencing tested in "Honey Sweet" can be used to develop other resistant stone fruits, such as peach, apricot, Japanese plum, and cherry, which are susceptible to PPV. Studies show that "Honey Sweet" plum fruit quality is excellent, and productivity is very good [64]. The international collaborative program that bred "Honey Sweet" shows the potential of public funding for research and development, which provides safe, efficacious genetic engineering products for the benefit of growers and consumers. "Honey Sweet" plum provides an interesting germplasm source for PPV control elsewhere.

\subsection{Banana: Resistance to Xanthomonas Wilt in the Great Lakes Region of Africa}

Banana and plantain (Musa sp.) are among the most important food crops in the tropics. They are grown in more than 120 countries over an area of about 10 million hectares and an annual production of 130 million tonnes [71]. Approximately one third of the bananas produced globally are grown in sub-Saharan Africa where the crop provides more than $25 \%$ of food energy requirements for more than 100 million people. Xanthomonas wilt caused by the bacterium Xanthomonas campestris pv. musacearum is one of the most important diseases and currently considered as the biggest threat to banana production in the Great Lakes Region of Africa including Uganda, Democratic Republic of Congo, Rwanda, Kenya, Tanzania and Burundi. The pathogen is highly contagious and its spread has endangered the livehood of millions of farmers who rely on banana for food and income. The development of disease resistant bananas remains a high priority since farmers are reluctant to employ labor-intensive disease control measures and there is no host plant resistance among banana cultivars. The International Institute of Tropical Agriculture (IITA), in a partnership with Uganda's National Agricultural Research Organisation (NARO) and other institutions have developed transgenic bananas constitutively expressing the hypersensitivity response-assisting protein (Hrap) and the plant ferredoxin-like protein (Pflp) genes from sweet pepper (Capsicum annuum). These transgenic bananas have exhibited enhanced resistance to $X$. campestris pv. musacearum [72]. The best 65 transgenic plants expressing Hrap and Pflp and not showing any infection symptoms after artificial inoculation of potted plants with banana Xanthomonas wilt in the screenhouse were evaluated in a confined field trial in Uganda, against this bacterial wilt for two successive crop cycles [73]. Transgenic bananas did not show significant changes in plant morphology versus the non-transgenic banana cultivar. Most transgenic bananas had significantly higher host plant resistance than the non-transgenic control. After testing them as mother plants and first ratoon plants, 11 transgenic bananas were rated as having absolute resistance; i.e., similar to the reference, resistant wild not-edible banana species Musa balbisiana. Their plant phenotype and the bunch weight and size were similar to the non-transgenic counterparts. Transgenic bananas showing Xanthomonas wilt 
resistance will undergo multi-environment testing in Uganda. They will be further evaluated for environmental and food safety according to the country's biosafety regulations, risk assessment and management, plus procedures for seed registration and release [74].

\section{Transgenic Vegetables and Nutritional Health Benefits}

As we saw above transgenic crops, enable plant breeders to bring favorable genes, often previously inaccessible, into already elite cultivars, improving their value considerably and offering unique opportunities for extending shelf-life of the produce and for controlling insects, viruses and other pathogens. Conventional plant breeding that utilizes non-transgenic approaches will remain the backbone of vegetable and fruit genetic improvement strategies. However, transgenic crop cultivars should not be excluded as products capable of contributing to more nutritious and healthy food. In this chapter we will describe several advances of transgenic vegetables to nutritional quality and health benefits, very important for consumers.

Tomato fruit and its processed products are the principal dietary sources of carotenoids such as lycopene and $\beta$-carotene. Therefore, there is considerable interest in elevating the levels of carotenoids in tomato fruit by genetic manipulation and thereby improving the nutritional quality of the crop. To enhance the carotenoid content and profile of tomato fruit, Romer et al. [75] have produced transgenic lines containing a bacterial carotenoid gene ( $c r t I)$ encoding the enzyme phytoene desaturase, which converts phytoene into lycopene. Expression of this gene in transgenic tomato plants of the cultivar "Ailsa Cray" did not elevate total carotenoid levels. However, the $\beta$-carotene content increased about threefold, up to $45 \%$ of the total carotenoid content. The alteration in carotenoid content of these transgenic tomatoes did not affect growth and development. Levels of noncarotenoid isoprenoids were unchanged in the transformants. The phenotype has been found to be stable and reproducible over at least four generations. Fraser et al. [76] reported also an increase in tomato fruit carotenoids phytoene, lycopene, $\beta$-carotene and lutein in cultivar “Ailsa Craig”. Phytoene synthase from the bacterium Erwinia uredovora $(c r t B)$ has been overexpressed in tomato cultivar. Fruit-specific expression was achieved by using the tomato polygalacturonase promoter, and the CRTB protein was targeted to the chromoplast by the tomato phytoene synthase-1 transit sequence. Total fruit carotenoids of primary transformants (T(0)) were two-to fourfold higher than the controls, whereas phytoene, lycopene, $\beta$-carotene, and lutein levels were increased 2.4-, 1.8-, and 2.2-fold, respectively. The biosynthetically related isoprenoids, tocopherols plastoquinone and ubiquinone were unaffected by changes in carotenoid levels. The progeny (T(1) and T(2) generations) inherited both the transgene and phenotype. Ripe tomato fruits accumulate large amounts of lycopene and small amounts of $\beta$-carotene (pro-vitamin A). Lycopene is transformed into $\beta$-carotene by the action of lycopene beta-cyclase (beta-Lcy). Rosati et al. [77] introduced, via Agrobacterium-mediated transformation, DNA constructs aimed at upregulating (OE construct) or downregulating (AS construct) the expression of the beta-Lcy gene in a fruit-specific fashion. Three tomato transformants containing the OE construct show a significant increase in tomato fruit $\beta$-carotene content. The tomato fruits from these plants display different colour phenotypes, from orange to orange-red, depending on the lycopene/beta-carotene ratio. Fruits from AS transformants show up to 50\% inhibition of betaLcy expression, accompanied by a slight increase in lycopene content. Leaf carotenoid composition is unaltered in all transformants. In most transformants, an increase in total carotenoid content is observed with respect to the parental line. This increase occurs in the absence of major variations in the expression of endogenous carotenoid genes.

Current advances in genetic engineering of brassicas have enabled the production of plants with alterations in a range of vitamins or amino acids for improved human nutrition. Lu et al. [78] developed transgenic cauliflower with high levels of $\beta$-carotene accumulation, and Wahlroos et al. [79] produced oilseed Brassica rapa with increased histidine content. It is likely in the future that more transgenic vegetable brassicas with altered vitamin or amino acid content also will be developed.

Vitamin E, which includes tocopherols, is a lipid-soluble antioxidant. There are $\alpha, \beta, \gamma$, and $\delta$ isoforms of tocopherol with relative vitamin E potencies of $100 \%, 50 \%, 10 \%$, and $3 \%$, respectively. Conversion of $\gamma$-tocopherol to $\alpha$-tocopherol in vegetable crops could increase their value and importance in human health because vitamin E reduces the risk of several serious disorders (e.g., cardiovascular diseases and cancer), slows aging and enhances the function of the immune system. Cho et al. [80] developed transgenic lettuce plants of the cultivar "Chungchima” expressing a cDNA encoding $\gamma$-tocopherol methyltransferase from Arabidopsis thaliana to improve tocopherol composition. Transgene inheritance and expression in transformed plants increased enzyme 
activity and conversion of $\gamma$-tocopherol to the more potent $\alpha$ form.

Folate deficiency, regarded as a global health problem, causes neural tube defects and other human diseases. Folates are synthesized from pteridine, $p$-aminobenzoate (PABA), and glutamate precursos. Díaz de la Garza et al. [81] [82] developed trangenic tomatoes by engineering fruit-specific overexpression of GTP cyclohydrolase I that catalyzes the first step of pteridine synthesis and amynodeoxychorismate synthase that catalyzes the first step of PABA synthesis. Vine-ripened fruits contained on average 25-fold more folate than controls by combining PABA- and pteridine-overproduction traits through crossbreeding of transgenic tomato plants. The achieved folate level provides a complete adult daily requirement with less than one standard serving.

Vegetables also offer consumers a diverse mixture of nutrients that promote human health more beneficially than dietary supplements. However, the ingestion of plant-based diets rather than diets that rely primarily on animal products could limit the intake of essential nutrients such as calcium (Ca). Consequently, genetically engineering vegetables containing increase Ca levels may boost Ca uptake, thereby reducing the incidence of Ca deficiencies such as osteoporosis. In this regard, Park et al. [83] modified carrots to express increased levels of the plant Ca transporter sCAX1. These carrot lines were fertile and displayed no adverse phenotypes. Further, mice and human feeding trials demonstrated increased Ca absorption from sCAX1-expressing transgenic carrots vis-à-vis controls [84]. This research supports alternative means of biofortifying vegetables with bioavailable Ca. Zinc is also an essential element in human nutrition, as its deficiency severely impairs organ function. In experiments to fortify lettuce with this element, Zuo et al. [85] used Agrobacterium-mediated gene delivery of a mouse metallothionein mutant $\beta$-cDNA in the lettuce cultivar "Salinas 88". The concentration of zinc in the lettuce transgenic plants increased to $400 \mu \mathrm{g} / \mathrm{g}$ dry weight, which is considerably higher than in wild-type plants.

Flavonoids are polyphenols whose dietary intake has the potential to prevent chronic diseases. Schijlen et al. [86] introduced heterologous, flavonoid pathway genes—stilbene synthase, chalcone synthase, chalcone reductase, chalcone isomerase, and flavone synthase - to produce novel flavonoids in tomato fruit. These novel flavonoids-flavones and flavonols increased threefold, mostly in the Q12 peel, which had higher total antioxidant capacity. These findings add further support to the potential of engineering tomato fruit for accumulation of high levels of beneficial nutrients. Similarly, the poliphenol resveratrol, a stilbene, shows cancer chemo-preventative activity and may prevent coronary heart disease and arteriosclerosis. Liu et al. [87] in a quantitative analysis showed that resveratrol in transgenic lettuce plants was $56.0 \pm 5.52 \mu \mathrm{g} / \mathrm{g}$ leaf fresh weight, which is comparable to that in the skin of grape fruit (Citrus $\times$ paridisi Macfad.).

Flavonoids such as anthocyanins are known as antioxidants in vitro and can reduce the risk of many diseases related to aging. However, some vegetable brassicas, such as cauliflower, are low in anthocyanins. In an attempt to manipulate pigment biosynthesis to increase the health benefits of brassica vegetables, the effect of a regulatory locus of flavonoid content was assessed. Agrobacterium tumefaciens-mediated transformation of a Brassica oleracea line, selected for high transformation ability by Sparrow et al. [88], was used to produce plants transgenic for the maize $l c$ (leaf color) locus. $l c$ is a regulatory gene in the anthocyanin pathway, and it is expected that its presence will increase the flavonoid content. Seedling explants were co-cultivated with Agrobacterium tumefaciens strain LBA4404 containing a binary vector Q27 with a neomycin phosphotransferase II (NPTII) gene. Under tissue culture conditions, lc-containing plants were green with no visible increase in anthocyanin production. However, after transfer to the greenhouse, the exposure to high light intensity led to visible signs of pigmentation within one week. Increased pigmentation was apparent in stems, petioles, main leaf veins, and sepals. lc-containing lines had 10 to 20 times higher levels of total anthocyanins than controls. In addition, antioxidant activity of $l c$-containing lines was 1.5 times higher than that of controls [89].

The unique flavor and odor of alliums is derived from the hydrolysis of organosulfur compounds, which produces pyruvate, ammonia, and volatile sulfur compounds [90]. This reaction is catalyzed by the enzyme alliinase, which is contained in vacuoles within cells and released upon disruption of the tissue [91]. Variations in the ratios of these volatile sulfur compounds are responsible for the difference in flavors and odors between Allium species [90]. Along with health and nutritional benefits associated with these compounds, these thiosulfides are also major contributors to the bitter taste of some onions [90] [92]. Three sets of transgenic onion plants containing antisense alliinase gene constructs (a CaMV 35S-driven antisense root alliinase gene, a CaMV 35S-driven antisense bulb alliinase, and a bulb alliinase promoter-driven antisense bulb alliinase) have been recently produced [93]. Results from the antisense bulb alliinase lines have been much more encouraging, and three lines were produced with barely detectable bulb alliinase levels and activity. Progress has been confounded by the poor survival of transgenic plants. Crossing a non-transgenic open-pollinated parental line with a transgenic pa- 
rental plant carrying a single transgene in the hemizygous state has conducted to a transgenic hybrid onion seed from these transgenic lines. Some resulting seed produced by the non-transgenic parents will be hemizygous for the transgene and can be selected to give F1 heterozygous individuals containing the transgene. Self-fertilization of these individuals produces homozygous, hemizygous, and null $\mathrm{F}_{2}$ progeny for the transgene locus. These homozygous individuals can then be used to generate the bulk seed required for the production of commercial transgenic onion lines with less bitter taste. In attempts to reduce bitterness in lettuce, Sun et al. [94] cloned the gene for the sweet and taste, modifying protein miraculin from the pulp of berries of Richadella dulcifica, a West African shrub. This gene, with the CaMV 35S promoter, was introduced into the lettuce cultivar "Kaiser" using A. tumefaciens GV2260. Expression of this gene in transgenic plants led to the accumulation of significant concentrations of the sweet-enhancing protein. People suffering diabetes may use Miraculin as a food sweetener, which is active at extremely low concentrations. The first successful study conducted to engineer the taste of tomato fruit involved transformation of tomato with the thaumatin gene from the African plant katemfe (Thaumatococcus daniellii) [95]. Thaumatin is a sweet-tasting protein. Fruit fromT2 transgenic plants tasted sweeter than the control plants, leaving a unique and sweet-specific aftertaste.

Food safety can also be enhanced through transgenic approaches. The first transgenic cassava plants became available in the mid-1990s [96]-[98] as plants with reduced cyanogenic content [99]-[101], which can benefit resource-poor people in rural Asia and Africa where this starchy root crop is the base of their diet.

Some vegetables, mainly tomato, are also genetically modified to become a vaccine delivery. Plant delivery of oral vaccines has attracted much attention because this strategy offers several advantages over vaccine delivery by injection [102]-[104]. Oral vaccines also offer the hope of more convenient immunization strategies and a more practical means of implementing universal vaccination programs worldwide. Tomato has been tested for expression of vaccines that can address human health issues of the developing world. Transgenic tomato plants potentially can bring several positive effects and improve human health. McGarvey et al. [105] engineered tomato plants of cultivar "UC82b" to express a gene encoding a glycoprotein (G-protein), which coats the outer surface of the rabies virus. The recombinant constructs contained the G-protein gene from the environmental risk assessment strain of rabies virus. The G-protein was expressed in leaves and fruit of the transgenic plants, and it was found localized in Golgi bodies, vesicles, plasmalemma, and cell walls of vascular parenchyma cells.

Ma et al. [106] overexpressed hepatitis E virus (HEV) open reading frame 2 partial gene (HEV-E2) in tomato plants to investigate its expression in transformants, the immunoactivity of expressed products, and explore the feasibility of developing a new type of plant-derived HEV oral vaccine. The recombinant protein was produced at $61.22 \mathrm{ng} / \mathrm{g}$ fresh weight in tomato fruits and $6.37-47.9 \mathrm{ng} / \mathrm{g}$ fresh weight in the leaves of the transformants. It was concluded that the $H E V$-E2 gene was correctly expressed in transgenic tomatoes and that the recombinant antigen derived had normal immunoactivity. These transgenic tomato plants are valuable tools for the development of edible oral vaccines. Chen et al. [107] developed an effective antiviral agent against enterovirus 71 (EV71), which causes seasonal epidemics of hand, foot, and mouth disease associated with fatal neurological complications in young children, by transforming the gene for VP1 protein - a previously defined epitope and also a coat protein of EV71 - in tomato plant. VP1 protein was first fused with sorting signals to enable it to be retained in the endoplasmic reticulum of tomato plant, and its expression level increased to $27 \mathrm{mg} / \mathrm{g}$ in fresh tomato fruit. Transgenic tomato fruit expressing VP1 protein was then used as an oral vaccine, and the development of VP1specific fecal IgA and serum IgG were observed in BALB/c mice. Additionally, serum from mice fed transgenic tomato could neutralize the infection of EV71 to rhabdomyosarcoma cells, indicating that tomato fruit expressing VP1was successful in orally immunizing mice. Moreover, the proliferation of spleen cells from orally immunized mice was stimulated by VP1 protein and provided further evidence of both humoral and cellular immunity. Results of this study not only demonstrated the feasibility of using transgenic tomato as an oral vaccine to generate protective immunity in mice against EV71 but also the probability of enterovirus vaccine development. The Gram-negative bacterium Yersinia pestis causes plague, which has affected human health since ancient times. It is still endemic in Africa, Asia, and the American continent. There is the urgent need for a safe and cheap vaccine due to the increasing reports of the incidence of antibiotic-resistant strains and concern with the use of Y. pestis as an agent of biological warfare. Out of all the Y. pestis antigens tested, only F1 and Vinduce present a good protective immune response against a challenge with the bacterium [108]. Alvarez et al. [109] reported the expression in tomato of the $Y$. pestis F1-Vantigen fusion protein. The immunogenicity of the F1-V transgenic tomatoes was confirmed in mice that were injected subcutaneously with bacterially produced F1-V fusion protein and boosted orally with transgenic tomato fruit. Expression of the plague antigens in the 
tomato fruit allowed producing an oral vaccine candidate without protein purification and with minimal processing technology, offering a good system for a large-scale vaccination programs in developing countries. The future of edible plant-based vaccines through transgenic approaches will depend on producing them safely on sufficient amounts.

\section{Transgenic Vegetables and Integrated Pest Management}

The production of vegetables worldwide tends to be on smaller areas and in more diversified holdings than field crops such as cotton, canola, cereals and soybeans. Vegetables are often in more complex agricultural systems where insects may move from one crop to the next within the same farm. How this will impact the use and effects of transgenic vegetable plants in the agricultural landscape can be complex. Growing multiple insect-resistant transgenic vegetable plants in the same area and exposure of a polyphagous insect to the same $B t$ protein expressed in the different vegetable species will challenge conventional strategies developed for transgenic cotton or maize cultivars. Thoughtful consideration therefore will be needed before choosing what toxins vegetable plants should express. The selection should be based not only on what will be an effective toxin against the target insect but which toxins are already in use in other vegetable crops that may be hosts for the target insect. Additionally, the difficulty of sampling insect populations for resistant alleles will take on a higher level of complexity in a diversified vegetable system.

Further consideration should also be given to the effects on nontarget organisms within diversified transgenic vegetable plantings. Hoheisel and Fleischer [110] investigated the seasonal dynamics of coccinellids and their food (aphids and pollen) in a vegetable farm system containing plantings of Bt-sweet corn, Bt-potato, and transgenic insect-resistant squash in northeastern USA. Their results indicated that the transgenic vegetable crops provided conservation of coccinellids and resulted in a $25 \%$ reduction in insecticide use. In a similar study with these same crops, Leslie et al. [111] compared the soil surface dwelling communities of Coleoptera and Formicidae in the transgenic crops and their isolines and found no differences in species richness and species composition but found that the transgenic vegetables required fewer insecticide applications. Such results make clear that transgenic technology can be introduced within vegetable integrated pest management (IPM) systems and that transgenic vegetables can offer novel and effective ways of controlling insects and the pathogens they transmit.

Virus-resistant transgenic plants are particularly valuable if no germplasm source of resistance has been identified or if host plant resistance is difficult to transfer into elite cultivars by traditional breeding methods due to incompatibility barriers or links to undesired traits. In such cases, engineered host plant resistance may be the only viable option to develop virus resistant cultivars. Growers can also use virus-resistant transgenic vegetables as a trap crop by growing it as a border around the non-transgenic vegetable crop and allowing it to cleanse viruliferous aphids.

In small, diversified vegetable plantings typical of those found throughout the developing world, the challenges for regulatory oversight of transgenic plants are immense. In these countries, farmers will likely save transgenic seed and move transgenic seed between locations, and some transgenic products may move into markets that do not permit these products. These concerns will be lessened if people consume the produce from transgenic vegetables locally after they are released and grown following national biosafety guidelines. However, it is likely that violations will occur, and this will challenge legal systems.

While each vegetable has its own set of one or more key pests, other pests can also be problematic. Traditional broad-spectrum insecticides often control a suite of pest insects. Thus, when transgenic vegetables are introduced into production systems, other methods of control will have to be applied or developed for secondary pests, e.g., biological control of secondary pests or use of selective insecticides, applied either as seed treatments or foliar sprays, may be necessary.

Integrated pest management could benefit from some herbicide-tolerant crops, if alternative nonchemical methods can be applied first to control weeds and the specific herbicide could be used later, only when and where the economic threshold of weeds is surpassed [112]. Herbicide-tolerant transgenic crops can help reducing plough in fields, thereby saving fuel because of less tractor use, which also protects the structure of the soil by reducing its erosion. Repeated use of herbicides in the same area may also create problems of weed herbicide resistance [113]. Although the risk of herbicide-resistant genes in vegetables is globally lower than in field crops because many vegetables are consumed in the vegetative stage. 


\section{Markets, Politics and the Power of Advocacy Groups}

Although transgenic cultivars have proven to be a powerful tool for pest management, and their use has been accompanied by reduced dependence on pesticides, fertilizers and other inputs, and dramatic economic and environmental benefits [114], many countries are still engaged in discussions about potential negative impacts of these crops on the environment, nontarget organisms, food safety, the unintentional spread of transgenic traits into conventionally bred-crop or landrace gene pools of the same species particularly in centers of crop diversity or origin, and questions of seed ownership. Fear about potential negative effects of transgenic crops has led to the implementation of very stringent regulatory systems in several countries and regulations that are far more restrictive for transgenic crops than for other agricultural technologies [115]. Consumer antagonism has precluded many farmers and consumers from sharing the benefits that these crops can provide. Critics also claim that adoption of transgenic crops benefits multinational seed corporations while hurting small farmers because of the additional investments required for growing these crops successfully. These unfounded concerns are present despite the highly successful and rapid adoption of transgenics in maize, soybeans, canola and cotton in many countries of the world.

Farmers and consumers will try to influence political decision making in favor of any technology if they expect to gain from it. The political power of farmers in the developed world was used effectively to gain access to large farm subsidies supported in part by fiscal resources and in part by artificially high consumer prices. Their market power however gradually deteriorated as consumers gained a greater say in the marketplace for food. On the contrary, developing world farmers possess very limited political power and have been taxed rather than subsidized by their governments.

Another factor that has led to differential perspectives between rich and poor countries is the relative power possessed by civil society groups including advocacy activists opposed to genetic engineering in food and agriculture. These activists have been very successful in influencing the debate, and consumer and government attitudes towards genetically modified food in Europe and are also gaining power in selected developing countries. While the European governments have tended to follow the expressed desires by advocacy groups and a majority of consumers opposed to genetically engineered food, the USA and Canadian governments support the farm sector and the private sector engaged in the development and deployment of modern biotechnology-crops. The large majority of the population of China and India (the largest consumers of vegetables) also are in favor of the use of modern biotechnology for both human diseases and pest-resistant crops, while the European countries are much more in favor of the use of modern biotechnology for human diseases than for food and agriculture. Some developing countries are considering the commercialization of genetically modified crops but they have been warned by the European Union that they may lose the European market not only for the commodities that have been genetically modified but possibly also for those that have not been geneticaly modified. This situation happened for vegetables with Africa exporter countries and seems to be also relevant with India government decision respecting Bt-eggplant. Developing countries who might wish to use genetic modification to improve agricultural productivity and nutritional qualities of their foods might therefore be faced with a choice between doing so for the domestic market while losing export opportunities or foregoing the potential benefits to its own people while maintaining export opportunities.

One could argue that the European consumer has gained a great deal of political power over agriculture in her capacity as a consumer, while still agreeing to provide large subsidies to agriculture in her capacity as a taxpayer. The possibility that the application of modern biotechnology in European agriculture could reduce the need for farm subsidies does not seem to enter into the European debate. To the extent this potential contradiction has been considered by consumers and governments, the conclusion seems to be that consumers prefer to pay farmers not to produce genetically modified food either through additional subsidies or through high food prices, at least until now. Such a contradiction is not prevalent in the United States and Canada.

The great opposition made by advocacy groups mainly in Europe and Japan to transgenic crops about food safety and possible health problems is denied by scientific data and various international and national organizations worldwide. Transgenic crops must pass a rigorous assessment based on scientific data of any potential risks. The objective of this appraisal has been to determine whether the transgenic crop is as safe as its conventional counterpart before transgenic modification. For this purpose, scientific data are provided to be reasonably confident that it will not damage consumers' health. Several organizations have stated that transgenic crops approved for commercialization, do not pose more risk to human health than conventional crops. The Food and 
Agriculture Organization of the United Nations [116], the Royal Society of London, the US National Academy of Sciences, the Brazilian Academy of Sciences, the Chinese Academy of Sciences, the Indian National Science Academy, the Mexican Academy of Sciences and the Third World Academy of Sciences [117], the World Health Organization [118], the American College of Nutrition [119], the American Society of Toxicology [120], the British Medical Association [121], and the Union of German Academies of Sciences and Humanities [122], among others, have stated that transgenic crops approved for commercialization, do not pose more risk to human health than conventional crops, and they should be considered as safe as conventional ones.

The World has witnessed a steady increase of transgenic crop area in the last 18 years. The potential impacts on human and animal health have been subject to extensive research, and no evidence has been found against transgenic crops. Some people, however continue to argue the potential long-term risks but without indicating what those risk maybe. Recently, the Federal Office of Consumer Protection and Food Safety of Germany and partners [123] issued the report "Biological and Ecological Evaluation towards Long-term Effects" (also known as the BEETLE report) with the aim of providing scientific data to the European Commission. The BEETLE report reviewed in excess of 100 publications and consulted 52 experts in health issues to assess the possible long-term effect of transgenic crops on the health of consumers and the environment. This report concluded that so far, no adverse effects to human health from eating GM food have been found. The report further stated that although unexpected negative effects are known in conventional crops, none has yet been detected in transgenic crops. The report concludes that there is a negligible probability for adverse effects to consumers' health in the long term.

\section{The Case for Cisgenic Vegetables and Fruits?}

Transgenic vegetables lacking any undesired genes will be useful to overcome any potential resistance for the deployment of such genetically engineered crops [125]. Some systems are available for releasing marker-free transgenic crops, e.g. through co-transformation or highly efficient gene transfer protocols for engineering plants without any marker-aided selection that require the screening to identify transgenic events, and recombination for removal of specific undesired gene sequences from transgenic plants.

Progress in crop genome sequencing, high resolution genetic mapping and precise phenotyping will accelerate the discovery and use of functional alleles and allelic variation that are associated with traits of interest for plant breeding [124]. Genome sequencing and annotation include an increasing range of species such as apple, banana/plantain, (common) bean, cacao, cassava, chickpea, Chinese cabbage, citrus, coffee, (diploid) cotton, cucumber, eggplant, grape, model legumes, maize, melon, oil palm, oilseed rape, papaya, peach, pepper, pigeonpea, potato, rice, sorghum, sugarcane, soybean, (woodland) strawberry, tomato and watermelon among other plant species [https://genomevolution.org/wiki/index.php/Sequenced_plant_genomes\#Rate_of_Publication]. Perhaps, one day further research on the genome of a plant species from a drought-prone environment may assist to breeding hardier and water efficient related crops due to gene synteny.

The use of plant-derived genes for introducing useful traits and plant-derived promoters will also overcome some concerns about the deployment of genetically-engineered vegetables. In this regard, cisgenesis addresses some negative views regarding the use of genes from non-crossable species for breeding vegetable crops. Cisgenesis involves only genes from the plant itself or from a crossable close relative, and these genes could also be transferred by conventional breeding methods. Crop wild relatives are therefore a valuable source of traits for cisgenesis. For example, wild Solanum species from South America are sources of alleles for improving tomato adaptation to climate change and other abiotic stresses: $S$. chilense grows in the desert due to its long primary roots and extensive secondary root system, whereas $S$. pennellii increases its water use efficiency under drought, and S. cheesmanii or S. peruvianum may grow in salty coastal areas. Schouten et al. [125] [126] argued very eloquently that regulations for genetically modified organisms should be altered to exempt cisgenesis because it respects species barriers. They conclude that regulators should treat cisgenic plants as conventionally bred plants regarding biosafety issues. Of course, any cisgenic plants need to be assessed for confirming they only bear the intended modifications and no other foreign gene(s). Very recently, Eriksson et al. [127] warn that cisgenic also poses risks and brings additional costs. They further argue that promoting cisgenics may lead to a lack of trust that public places in science. People may ask why scientists told them for several decades that transgenic crops were not more risky than crossbred crops. 


\section{Outlook}

Vegetables are grown worldwide, on large and small farms, on good and marginal land, and by large commercial growers and small subsistence farmers. Transgenic cultivars can improve nutritional quality and make important contributions to sustainable vegetable production by overcoming some limiting factors in vegetable production, e.g. pathogens (bacteria, fungi, viruses), pests (insects and nematodes), and weeds, which are not easily addressed through conventional breeding alone. They could also help for reducing pesticide residues and human poisoning, and reducing costs in horticulture. However, as noted by Ortiz and Smale [115], before transgenic cultivars can be made available to vegetables farmers, particularly in the developing world, several hurdles must be overcome. At this time, the most important of these appear to be related to intellectual property management, public awareness, biosafety guidelines, and food safety protocols. Appropriate measures needs to be sought to overcome such hurdles.

The high cost of satisfying biotechnology regulatory requirements is prohibitive for most vegetable crops, restricting the commercial availability of this powerful technology to a few commodities crops such as cotton, maize, soybean and canola. In addition, high regulatory hurdles reduce or eliminate opportunities for small companies and public institutions to commercialize products that might appeal directly to consumers or address human nutritional needs. The lost opportunity costs and reduced innovations due to underutilization of modern biotechnology methods in vegetable cultivar development are significant, particularly in light of the documented benefits of these products. Thus it is necessary to develop cost-efficient benefit/risk analysis systems for products of biotechnology [128] [129].

Countries vary in their market standards and acceptance of transgenic crops. The advantages of transgenic breeding should provide incentive for integration of this method into the amelioration of challenges for vegetables and horticultural production, if consumer fears are overcome or eased. The future of transgenic vegetables may be in the developing world, especially China and India, which account for $40 \%$ of the world population, and grow and consume in excess of $60 \%$ of the world's vegetables. They already adopted Bt-cotton, and it is likely that Bt-rice will be reaching soon farmers in China. The acceptance of transgenic vegetables in both countries will likely hasten their adoption in other parts of the world and allow farmers to use these crops.

Distinct perspectives leading to different policy options and standards may conflict with the current globalization market. Some policy options that may be appropriate for the developed world are sometimes inappropriate for the developing world. Transgenic crops are not silver bullets for achieving food security but coupled with traditional knowledge and conventional agriculture may be a powerful tool for making available affordable food to poor farmers and consumers. Modern biotechnology can provide products with the potential for reducing farming costs, enhancing agricultural productivity, ensuring food supply, alleviating rural poverty, promoting sustainable use of natural resources, protecting the environment and preserving biodiversity. Biotechnology-derived crops will succeed in farming systems if clear advantages and safety are demonstrated to both growers and consumers.

\section{References}

[1] Dias, J.S. and Ryder, E. (2011) World Vegetable Industry: Production, Breeding, Trends. Horticultural Reviews, 38, 299-356.

[2] Keatinge, J.D.H., Waliyar, F., Jammadass, R.H., Moustafa, A., Andrade, M., Drechsel, P., Hughes, J.A., Kardivel, P. and Luther. K. (2010) Re-Learning Old Lessons for the Future of Food: By Bread Alone No Longer-Diversifying Diets with Fruit and Vegetables. Crop Science, 50, S51-S62. http://dx.doi.org/10.2135/cropsci2009.09.0528

[3] Kays, S.J. and Dias J.S. (1995) Common Names of Commercially Cultivated Vegetables of the World in 15 Languages. Economic Botany, 49, 115-152. http://dx.doi.org/10.1007/BF02862917

[4] Kays, S.J. (2011) Cultivated Vegetables of the World: A Multilingual Onomasticon. Wageningen Academic Publishers, Wageningen. http://dx.doi.org/10.3920/978-90-8686-720-2

[5] Krattinger, A. (1998) The Importance of Ag-Biotech to Global Prosperity. ISAAA Briefs No. 6, The International Service for the Acquisition of Agri-biotech Applications, Ithaca, NY, 11.

[6] Pimentel, D. (1997) Techniques for Reducing Pesticide Use. Economic and Environmental Benefits. Wiley, New York.

[7] Dias, J.S. and Ortiz, R. (2012) Transgenic Vegetable Crops: Progress, Potentials and Prospects. Plant Breeding Reviews, 35, 151-246.

[8] Asian Vegetable Research and Development Center (2001) Fact Sheet: Eggplant Fruit and Shoot Borer. AVRDC, Tai- 
nan.

[9] Choudhary, B. and Gaur, K. (2009) The Development and Regulation of Bt Brinjal in India. ISAAA Brief No. 38, International Service for Acquisition of Agri-Biotech Applications, Ithaca, NY.

[10] Siritunga, D. and Sayre, R.T. (2003) Generation of Cyanogen-Free Transgenic Cassava. Planta, 217, 367-373. http://dx.doi.org/10.1007/s00425-003-1005-8

[11] Siritunga, D. and Sayre, R.T. (2004) Engineering Cyanogen Synthesis and Turnover in Cassava (Manihot esculenta). Plant Molecular Biology, 56, 661-669. http://dx.doi.org/10.1007/s11103-004-3415-9

[12] Siritunga, D., Arias-Garzon, D., White, W. and Sayre, R.T. (2004) Over-Expression of Hydroxynitrile Lyase in Transgenic Cassava Roots Accelerates Cyanogenesis and Food Detoxification. Plant Biotechnology Journal, 2, 37-43. http://dx.doi.org/10.1046/j.1467-7652.2003.00047.x

[13] Kramer, M.G. and Redenbaugh, K. (1994) Commercialization of a Tomato with an Antisense Polygalacturonase Gene: The FLAVR SAVRTM Tomato Story. Euphytica, 79, 293-297. http://dx.doi.org/10.1007/BF00022530

[14] Hamilton, A., Lycett, G. and Grierson, D. (1990) Antisense Gene That Inhibits Synthesis of the Hormone Ethylene in Transgenic Plants. Nature, 346, 284-287. http://dx.doi.org/10.1038/346284a0

[15] Oeller, P.W., Wong, L.M., Taylor, L.P., Pike, D.A. and Theologis, A. (1991) Reversible Inhibition of Tomato Fruit Senescence by Antisense 1-Aminocyclopropane-1-Carboxylate Synthase. Science, 254, 437-439. http://dx.doi.org/10.1126/science.1925603

[16] Klee, H.J., Hayford, M.B., Kretzmer, K.A., Barry, G.F. and Kishore, G.M. (1991) Control of Ethylene Synthesis by Expression of a Bacterial Enzyme in Transgenic Tomato Plants. Plant Cell, 3, 1187-1193. http://dx.doi.org/10.1105/tpc.3.11.1187

[17] Good, X., Kellogg, J.A., Wagoner, W., Langhoff, D., Matsumura, W. and Bestwick, R.K. (1994) Reduced Ethylene Synthesis by Transgenic Tomatoes Expressing S-Adenosylmethionine Hydrolase. Plant Molecular Biology, 26, 781-790. http://dx.doi.org/10.1007/BF00028848

[18] Gianesi, L. and Carpenter, J. (1999) Agricultural Biotechnology: Insect Control Benefits. National Center for Food and Agricultural Policy, Washington DC.

[19] Qaim, M. (1998) Transgenic Virus Resistance Potatoes in Mexico: Potential Social Implications of North-South Biotechnology Transfer. ISAAA Briefing No. 7, International Service for Acquisition of Agri-Biotech Applications, Ithaca, NY.

[20] Thomas, P.E., Kaniewski, W.K. and Lawson, E.C. (1997) Reduced Field Spread of Potato Virus in Potatoes Transformed with the Potato Leafroll Virus Coat Protein Gene. Plant Disease, 81, 1447-1453. http://dx.doi.org/10.1094/PDIS.1997.81.12.1447

[21] Thornton, M. (2003) The Rise and Fall of New Leaf Potatoes. NABC Report, 15, 235-243.

[22] Grafius, E.J. and Douches, D.S. (2008) The Present and Future Role of Insect-Resistant Genetically Modified Potato Cultivars in IPM. In: Romeis, J., Shelton, A.M. and Kennedy, G.G., Eds., Integration of Insect-Resistant Genetically Modified Crops within IPM Programs, Springer Science + Business Media B.V., Dordrecht, 195-221. http://dx.doi.org/10.1007/978-1-4020-8373-0_7

[23] Guenthner, J.F. (2002) Consumer Acceptance of Genetically Modified Potatoes. American Journal of Potato Research, 79, 309-316. http://dx.doi.org/10.1007/BF02870167

[24] Visser, D. (2005) Guide to Potato Pests and Their Natural Enemies in South Africa. ARC-Roodeplaat Vegetable and Ornamental Plant Institute, Pretoria.

[25] Douches, D.S. and Grafius, E.J. (2005) Transformation for Insect Resistance. In: Razdan, M.K. and Mattoo, A.K., Eds., Genetic Improvement of Solanaceous Crops. Vol. 1: Potato, Science Publishers Inc., Enfield, NH, Plymouth, UK, 235266.

[26] Douches, D.S., Pett, W., Santos, F., Coombs, J., Grafius, E., Li, W., Metry, E.A., Nasr El-Din, T. and Madkour, M. (2004) Field and Storage Testing Bt Potatoes for Resistance to Potato Tuberworm (Lepidoptera: Gelichiidae). Journal of Economic Entomology, 97, 1425-1431. http://dx.doi.org/10.1603/0022-0493-97.4.1425

[27] Douches, D.S., Brink, J.A., Quemada, H., Pett, W., Koch, M., Visser, D., Maredia, K. and Zarka, K. (2007) Commercialization of Potato Tuber Worm Resistant Potatoes in South Africa. Proceedings of 6th World Potato Congress, Boise, 20-26 August 2006. http://www.potatocongress.org/congress/proceedings-2006/

[28] Douches, D.S., Brink, J.A., Quemada, H., Pett, W., Koch, M., Visser, D., Maredia, K. and Zarka, K. (2008) Commercialization of Potato Tuber Moth Resistant Potatoes in South Africa. In: Kroschel, J. and Lacey, L.A., Eds., Integrated Pest Management for the Potato Tuber Moth, Phthorimaea operculella (Zeller)_Potato Pest of Global Importance, Tropical Agriculture 20, Advances in Crop Research 10, Margraf Publishers GmbH, Weikersheim, 139-147.

[29] Cooper, S.G., Douches, D.S., Zarkas, K. and Grafius, E.J. (2009) Enhanced Resistance to Control Potato Tuberworm 
by Combining Engineered Resistance, Avidin, and Natural Resistance Derived from Solanum chacoense. American Journal of Potato Research, 86, 24-30. http://dx.doi.org/10.1007/s12230-008-9057-8

[30] Celis, B.C., Scurrah, M., Cowgill, S., Chumbiauca, S., Green, J., Franco, J., Main, G., Kiezebrink, D., Visser, R. and Atkinson, H.J. (2004) Environmental Biosafety and Transgenic Potato in a Centre of This Crop’s Diversity. Nature, 432, 222-225. http://dx.doi.org/10.1038/nature03048

[31] Scurrah, M., Celis-Gamboa, C., Chumbiauca, S., Salas, A. and Visser, R.G.F. (2008) Hybridization between Wild and Cultivated Potato Species in the Peruvian Andes and Biosafety Implications for Deployment of GM Potatoes. Euphytica, 164, 881-892. http://dx.doi.org/10.1007/s10681-007-9641-x

[32] ISAAA (2008) Bt Brinjal in India. Pocket K 35. International Service for Acquisition of Agri-Biotech Applications, Ithaca, NY.

[33] Krishna, V.V. and Qaim, M. (2008) Potential Impacts of Bt Eggplant on Farmers' Health in India. Agricultural Economics, 38, 167-180. http://dx.doi.org/10.1111/j.1574-0862.2008.00290.x

[34] Krishna, V.V. and Qaim, M. (2007) Estimating the Adoption of Bt Eggplant in India: Who Benefits from Public-Private Partnership? Food Policy, 32, 523-543. http://dx.doi.org/10.1016/j.foodpol.2006.11.002

[35] Kolady, D. and Lesser, W. (2008) Can Owners Afford Humanitarian Donations in Agbiotech-The Case of Genetically Engineered Eggplant in India. Electronic Journal of Biotechnology, 11, 5. http://www.ejbiotechnology.info/content/vol11/issue2/full/5/

[36] Kameswara-Rao, C. (2010) Moratorium on Bt Brinjal: A Review of the Order of the Minister of Environment and Forests, Government of India. Foundation for Biotechnology Awareness and Education, Bangalore.

[37] Kinetz, E. (2010) India Halts Genetically Modified Eggplant Release. Greenbio. http://seattletimes.com/html/businesstechnology/2011022982_apasindiagmfood.html

[38] Jayaraman, K. (2010) Bt Brinjal Splits Indian Cabinet. Nature Biotechnology, 28, 296. http://dx.doi.org/10.1038/nbt0410-296

[39] Choudhary, B., Nasiruddin, K.M. and Gaur, K. (2014) The Status of Commercialized Bt Brinjal in Bangladesh. ISAAA Brief No. 47, International Service for Acquisition of Agri-Biotech Applications, Ithaca, NY.

[40] Gianessi, L.P., Silvers, C.S., Sankula, S. and Carpenter, J.E. (2002) Virus Resistant Squash. In: Plant Biotechnology: Current and Potential Impact for Improving Pest Management in US Agriculture. An Analysis of 40 Case Studies, National Center for Food and Agriculture Policy, Washington, DC, 75.

[41] Gaba, V., Zelcer, A. and Gal-On, A. (2004) Cucurbit Biotechnology-The Importance of Virus Resistance. In Vitro Cellular \& Developmental Biology-Plant, 40, 346-358. http://dx.doi.org/10.1079/IVP2004554

[42] Ochoa, J.P.A., Dainello, F., Pike, L.M. and Drews, D. (1995) Field Performance Comparison of Two Transgenic Summer Squash Hybrids to Their Parental Hybrid Lineage. HortScience, 30, 492-493.

[43] Clough, G.H. and Hamm, P.B. (1995) Coat Protein Transgenic Resistance to Watermelon Mosaic and Zucchini Yellow Mosaic Virus in Squash and Cantaloupe. Plant Disease, 79, 107-1109. http://dx.doi.org/10.1094/PD-79-1107

[44] Fuchs, M. and Gonsalves, D. (1995) Resistance of Transgenic Squash Pavo ZW-20 Expressing the Coat Protein Genes of Zucchini Yellow Mosaic Virus and Watermelon Mosaic Virus 2 to Mixed Infections by Both Potyviruses. BioTechnology, 13, 1466-1473. http://dx.doi.org/10.1038/nbt1295-1466

[45] Tricoli, D.M., Carney, K.J., Russell, P.F., McMaster, J.R., Groff, D.W., Hadden, K.C., Himmel, P.T., Hubbard, J.P., Boeshore, M.L. and Quemada H.D. (1995) Field Evaluation of Transgenic Squash Containing Single or Multiple Virus Coat Protein Gene Constructs for Resistance to Cucumber Mosaic Virus, Watermelon Mosaic Virus 2, and Zucchini Yellow Mosaic Virus. BioTechnology, 13, 1458-1465. http://dx.doi.org/10.1038/nbt1295-1458

[46] Fuchs, M., Tricoli, D.M., McMaster, J.R., Carney, K.J., Schesser, M., McFerson, J.R. and Gonsalves, D. (1998) Comparative Virus Resistance and Fruit Yield of Transgenic Squash with Single and Multiple Coat Protein Genes. Plant Disease, 82, 1350-1356. http://dx.doi.org/10.1094/PDIS.1998.82.12.1350

[47] Schultheis, J.R. and Walters, S.A. (1998) Yield and Virus Resistance of Summer Squash Cultivars and Breeding Lines in North Carolina. HortScience, 8, 31-39.

[48] Shankula, S. (2006) Quantification of the Impacts on US Agriculture of Biotechnology-Derived Crops Planted in 2005. http://www.ncfap.org/

[49] Lynch, R., Wiseman, B., Sumner, H., Plaisted, D. and Warnick D. (1999) Management of Corn Earworm and Fall Armyworm (Lepidoptera: Noctuidae) Injury on a Sweet Corn Hybrid Expressing a cryIA (b) Gene. Journal of Economic Entomology, 92, 1217-1222.

[50] Musser, F.R. and Shelton, A.M. (2003) Bt Sweet Corn and Selective Insecticides: Their Impacts on Sweet Corn Pests and Predators. Journal of Economic Entomology, 96, 71-80. http://dx.doi.org/10.1603/0022-0493-96.1.71

[51] Burkness, E.C., Hutchison, W.D., Bolin, P.C., Bartels, D.W., Warnock, D.F. and Davis, D.W. (2001) Field Efficacy of 
Sweet Corn Hybrids Expressing a Bacillus thuringiensis Toxin for Management of Ostrinia nubilalis (Lepidoptera: Crambidae) and Helicoverpa zea (Lepidoptera: Noctuidae). Journal of Economic Entomology, 94, 197-203. http://dx.doi.org/10.1603/0022-0493-94.1.197

[52] Hassel, R. and Shepard, B.M. (2002) Insect Population on Bacillus thuringiensis Transgenic Sweet Corn. Journal of Entomological Science, 37, 285-292.

[53] Speese, I.J., Kuhar, T.P., Bratsch, A.D., Nault, B.A., Barlow, V.M., Cordero, R.J. and Shen, Z. (2005) Efficacy and Economics of Fresh-Market Bt Transgenic Sweet Corn in Virginia. Crop Protection, 24, 57-64. http://dx.doi.org/10.1016/j.cropro.2004.06.008

[54] Rose, R. and Dively, G.P. (2007) Effects of Insecticide-Treated and Lepidopteran-Active Bt Transgenic Sweet Corn on the Abundance and Diversity of Arthropods. Environmental Entomology, 36, 1254-1268. http://dx.doi.org/10.1603/0046-225X(2007)36[1254:EOIALB]2.0.CO;2

[55] NASS (2007) Vegetables: 2006 Annual Summary. National Agricultural Statistics Service, Washington DC.

[56] Headrick, J. (2011) The Buzz on Sweet Corn. http://monsantoblog.com/2011/11/08/the-buzz-on-sweet-corn/

[57] Stuart, D. (2011) Biotech Sweet Corn Varieties Deliver Sustainable Benefits to Growers. Monsanto Newsroom, 8/8/2011. http://www.monsanto.com/newsviews/Pages/gmo-sweet-corn-variety-coming-soon.aspx

[58] Cordero, R., Morjan, W., Fabellar, A., Harty, J. and Subere, C.V. (2011) Potential Impact of Biotech Sweet Corn (MON $89034 \times$ MON 88017) on Pest Management in the Southern US. Proceedings of the 2011 ASHS Annual Conference, Waikoloa, 25-28 September 2011, S288. http://ashs.confex.com/ashs/2011/webprogram/Paper5706.html

[59] Lius, S., Manshardt, R.M., Fitch, M.M.M., Slightom, J.L., Sanford, J.C. and Gonsalves, D. (1997) Pathogen-Derived Resistance Provides Papaya with Effective Protection against Papaya Ringspot Virus. Molecular Breeding, 3, 161-168. http://dx.doi.org/10.1023/A:1009614508659

[60] Susuki, Y.I., Tripathi, S. and Gonsalves, D. (2007) Virus-Resistant Transgenic Papaya: Commercial Development and Regulatory and Environmental Issues. In: Punka, Z.K., De Boer, S.H. and Sanfaçon, H., Eds., Biotechnology and Plant Disease Mmanagement, CAB International, Wallinford, 436-461.

[61] Shelton, A.M. and Badenes-Perez, F.R. (2006) Concept and Applications of Trap Cropping in Pest Management. Annual Review of Entomology, 51, 285-308. http://dx.doi.org/10.1146/annurev.ento.51.110104.150959

[62] Fuchs, M. and Gonsalves, D. (2007) Safety of Virus-Resistant Transgenic Plants Two Decades after Their Introduction: Lessons from Realistic Field Risk Assessment Studies. Annual Review of Phytopathology, 45, 173-202. http://dx.doi.org/10.1146/annurev.phyto.45.062806.094434

[63] Ming, R., Hou, S., Feng, Y., Yu, Q., Dionne-Laporte, A., Saw, J.H., Senin, P., Wang, W., Ly, B.V., Lewis, K.L.T., Salzberg, S.L., Feng, L., Jones, M.R., Skelton1, R.L., Murray, J.E., Chen, C., Qian, W., Shen, J., Du, P., Eustice1, M., Tong, E., Tang, H., Lyons, E., Paull, R.E., Michael, T.P., Wall, K., Rice, D.W., Albert, H., Wang, M.L., Zhu, Y.J., Schatz, M., Nagarajan, N., Acob, R.A., Guan, P., Blas, A., Wai1, C.M., Ackerman, C.M., Ren, Y., Liu, C., Wang, J., Wang, J., Na, J.K., Shakirov, E.V., Haas, B., Thimmapuram, J., Nelson, D., Wang, X., Bowers, J.E., Gschwend, A.R., Delcher, A.L., Singh, R., Suzuki, J.Y., Tripathi, S., Neupane, K., Wei, H., Irikura, B., Paidi, M., Jiang, N., Zhang, W., Presting, G., Windsor, A., Navajas-Pérez, R.N., Torres, M.J., Feltus, F.A., Porter, B., Li, Y., Burroughs, A.M., Luo, M.C., Liu, L., Christopher, D.A., Mount, S.M., Moore, P.H., Sugimura, T., Jiang, J., Schuler, M.A., Friedman, V., Mitchell-Olds, T., Shippen, D.E., de Pamphilis, C.W., Palmer, J.D., Freeling, M., Paterson, A.H., Gonsalves, D., Wang, L. and Alam, M. (2008) The Draft Genome of the Transgenic Tropical Fruit Tree Papaya (Carica papaya Linnaeus). Nature, 452, 991-996. http://dx.doi.org/10.1038/nature06856

[64] Scorza, R., Callahan, A., Dardick, C., Cambra, M., Polak, J., Ravelonandro, M., Zagrai, I. and Malinowski, T. (1998) "Honey Sweet"-A Transgenic Plum Pox Virus Resistant Plum-From Laboratory and Experimental Field Plots to Regulatory Approval. Acta Horticulturae, 974, 57-63.

[65] Ravelonandro, M., Monsion, M., Teycheney, P.Y., Delbos, R. and Dunez, J. (1992) Construction of a Chimeric Viral Gene Expressing Plum Pox Virus Coat Protein. Gene, 120, 167-173. http://dx.doi.org/10.1016/0378-1119(92)90090-C

[66] Hily, J.-M., Scorza, R., Malinowski, T., Zawadzka, B. and Ravelonandro, M. (2004) Stability of Gene Silencing-Based Resistance to Plum Pox Virus in Transgenic Plum (Prunus domestica L.) under Field Conditions. Transgenic Research, 13, 427-436. http://dx.doi.org/10.1007/s11248-004-8702-3

[67] Malinowski, T., Cambra, M., Capote, N., Zawadzka, B., Gorris, M.T., Scorza, R. and Ravelonandro, M. (2006) Field Trials of Plum Clones Transformed with the Plum Pox Virus Coat Protein (PPV-CP) Gene. Plant Disease, 90, 1012 1018. http://dx.doi.org/10.1094/PD-90-1012

[68] Polak, J., Pivalova, J., Kundu, J.K., Jokes, M., Scorza, R. and Ravelonandro, M. (2008) Behavior of Transgenic Plum Pox Virus-Resistant Prunus domestica L. Clone C5 Grown in the Open Field under a High and Permanent Infection Pressure of the PPV-Rec Strain. Journal of Plant Pathology, 90, S1.33-S1.36.

[69] Ravelonandro, M., Scorza, R., Renaud, R. and Salesses, G. (1998) Transgenic Plums Resistant to Plum Pox Virus In- 
fection and Preliminary Results of Cross-Hybridization. Acta Horticulturae, 478, 67-71.

[70] Scorza, R., Callahan, A., Levy, L., Damsteegt, V. and Ravelonandro, M. (1998) Transferring Potyvirus Coat Protein Genes through Hybridization of Transgenic Plants to Produce Plum Pox Virus Resistant Plums (Prunus domestica L.). Acta Horticulturae, 472, 421-425.

[71] Food and Agricultural Organization (2009) Agriculture Data. FAO, Rome. http://faostat.fao.org

[72] Tripathi, L., Mwaka, H., Tripathi, J.N. and Tushemereirwe, W. (2010) Expression of Sweet Pepper Hrap Gene in Banana Enhances Resistance to Xanthomonas campestris pv musacearum. Molecular Plant Pathology, 11, 721-731.

[73] Tripathi, L., Tripathi, J.N., Kiggundu, A., Korie, S., Shotkoski, F. and Tushemereirwe, W.K. (2014) Field Trial of Xanthomonas Wilt Disease-Resistant Bananas in East Africa. Nature Biotechnology, 32, 868-870. http://dx.doi.org/10.1038/nbt.3007

[74] Tripathi, L. (2012) Transgenics in Crop Improvement Research at IITA. IITA Research for Development (R4D) Review, 8, 58-60.

[75] Romer, S., Fraser, P.D., Kiano, J.W., Shipton, C.A., Misawa, N., Schuch, W. and Bramley, P.M. (2000) Elevation of the Provitamin A Content of Transgenic Tomato Plants. Nature Biotechnology, 18, 666-669. http://dx.doi.org/10.1038/76523

[76] Fraser, P.D., Romer, S., Shipton, C.A., Mills, P.B., Kiano, K.W., Misawa, N., Drake, R.G., Schuch, W. and Bramley, P.M. (2002) Evaluation of Transgenic Tomato Plants Expressing an Additional Phytoene Synthase in a Fruit Specific Manner. Proceedings of the National Academy of Sciences of the United States of America, 99, 1092-1097. http://dx.doi.org/10.1073/pnas.241374598

[77] Rosati, C., Aquilani, R., Dharmapuri, S., Pallara, P., Marusic, C., Tavazza, R., Bouvier, F., Camara, B. and Giuliano, G. (2000) Metabolic Engineering of Beta-Carotene and Lycopene Content in Tomato Fruit. Plant Journal, 24, 413-419. http://dx.doi.org/10.1046/j.1365-313x.2000.00880.x

[78] Lu, S., van Eck, J., Zhou, X., Lopez, A.B., O’Halloran, D.M., Cosman, K.M., Conlin, B.J., Paolillo, D.J., Garvin, D.F., Vrebalov, J., Kochian, L.V., Kupper, H., Earle, E.D., Cao, J. and Li, L. (2006) The Cauliflower Or Gene Encodes a DnaJ Cysteine-Rich Domain-Containing Protein That Mediates High Levels of $\beta$-Carotene Accumulation. Plant Cell, 18, 3594-3605. http://dx.doi.org/10.1105/tpc.106.046417

[79] Wahlroos, T., Susi, P., Solovyev, A., Dorokhov, Y., Morozov, S, Atabekov, J. and Korpela, T. (2004) Increase of Histidine Content in Brassica rapa Subsp. oleifera by Over-Expression of Histidine-Rich Fusion Proteins. Molecular Breeding, 14, 455-462. http://dx.doi.org/10.1007/s11032-004-0902-2

[80] Cho, E.A., Lee, C.A., Kim, Y.S., Baek, S.H., Reyes, B.G. and Yun, S.J. (2005) Expression of $\gamma$-Tocopherol Methyltransferase Transgene Improves Tocopherol Composition in Lettuce (Lactuca sativa L.). Molecules and Cells, 19, 16-22.

[81] Diaz de la Garza, R.I., Quinlivan, E.P., Klaus, S.M.J., Basset, G.J.C., Gregory, J.F. and Hanson, A.D. (2004) Folate Biofortification in Tomatoes by Engineering the Pteridine Branch of Folate Synthesis. Proceedings of the National Academy of Sciences of the United States of America, 101, 13720-13725. http://dx.doi.org/10.1073/pnas.0404208101

[82] Diaz de la Garza, R.I., Gregory, J.F. and Hanson, A.D. (2007) Folate Biofortification of Tomato Fruit. Proceedings of the National Academy of Sciences of the United States of America, 104, 4218-4222. http://dx.doi.org/10.1073/pnas.0700409104

[83] Park, S., Kim, C.K., Pike, L.M., Smith, R.H. and Hirschi, K.D. (2004) Increased Calcium in Carrots by Expression of an Arabidopsis $\mathrm{H}^{+} / \mathrm{Ca}^{2+}$ Transporter. Molecular Breeding, 14, 275-282. http://dx.doi.org/10.1023/B:MOLB.0000047773.20175.ae

[84] Morris, J., Hawthorne, K.M., Hotze, T., Abrams, S.A. and Hirschi, K.D. (2008) Nutritional Impact of Elevated Calcium Transport Activity in Carrots. Proceedings of the National Academy of Sciences of the United States of America, 105, 1431-1435. http://dx.doi.org/10.1073/pnas.0709005105

[85] Zuo, X., Zhang, Y., Wu, B., Chang, X. and Ru, B. (2002) Expression of the Mouse Metallothionein Mutant $\beta \beta$-cDNA in the Lettuces (Lactuca sativa L.). Chinese Science Bulletin, 47, 558-562. http://dx.doi.org/10.1360/02tb9128

[86] Schijlen, E., Ric de Vos, C.H., Jonker, H., van den Broeck, H., Molthoff, J., van Tunen, A., Martens, S. and Bovy, A. (2006) Pathway Engineering for Healthy Phytochemicals Leading to the Production of Novel Flavonoids in Tomato Fruit. Plant Biotechnology Journal, 4, 433-444. http://dx.doi.org/10.1111/j.1467-7652.2006.00192.x

[87] Liu, S., Hu, Y., Wang, X., Zhong, J. and Lin, Z. (2006) High Content of Resveratrol in Lettuce Transformed with a Stilbene Synthase Gene of Partenocissus henryana. Journal of Agricultural and Food Chemistry, 54, 8082-8085. http://dx.doi.org/10.1021/jf061462k

[88] Sparrow, P.A.C., Dale, P.J. and Irwin, J.A. (2004) The Use of Phenotypic Markers to Identify Brassica oleracea Genotypes for Routine High-Throughput Agrobacterium Mediated Transformation. Plant Cell Reports, 23, 64-70. http://dx.doi.org/10.1007/s00299-004-0818-7

[89] Braun, R.H., Morrison, S.C., Schwinn, K.E. and Christey, M.C. (2006) Agrobacterium Mediated Transformation of 
Brassica oleracea with the Lc Locus. International Association for Plant Tissue Culture and Biotechnology, Beijing, 115.

[90] Randle, W.M. and Lancaster, J.E. (2002) Sulphur Compounds in Alliums in Relation to Flavour Quality. In: Brewster, J.L., Ed., Onions and Other Vegetable Alliums, CAB International, Wallingford, Oxfordshire, 329-356.

[91] Lancaster, J.E. and Collin, H.A. (1981) Presence of Alliinase in Isolated Vacuoles and of Alkyl Cysteine Sulphoxides in the Cytoplasm of Bulbs of Onion (Allium cepa L.). Plant Science Letters, 22, 169-176. http://dx.doi.org/10.1016/0304-4211(81)90139-5

[92] Almeida, D. (2006) Manual de Culturas Hortícolas. Vol. 1, Editorial Presença, Lisboa.

[93] Eady, C.C., Davis, S., Farrant, J., Reader, J. and Kenel, F. (2003) Agrobacterium tumefaciens Mediated Transformation and Regeneration of Herbicide Resistant Onion (Allium cepa) Plants. Annals of Applied Biology, 142, $213-217$. http://dx.doi.org/10.1111/j.1744-7348.2003.tb00243.x

[94] Sun, H.J., Cui, M.L., Ma, B. and Ezura, H. (2006) Functional Expression of the Taste Modifying Protein, Miraculin, in Transgenic Lettuce. FEBS Letters, 580, 620-626. http://dx.doi.org/10.1016/j.febslet.2005.12.080

[95] Bartoszewski, G., Niedziela, A., Szwacka, M. and Niemirowicz-Szczytt, K. (2003) Modification of Tomato Taste in Transgenic Plants Carrying a Thaumatin Gene from Thaumatococcus daniellii BENT. Plant Breeding, 122, 347-351. http://dx.doi.org/10.1046/j.1439-0523.2003.00864.x

[96] Li, H.Q., Sautter, C., Potrykus, I. and Pounti-Kaerlas, J. (1996) Genetic Transformation of Cassava (Manihot esculenta Crantz). Nature Biotechnology, 14, 736-740. http://dx.doi.org/10.1038/nbt0696-736

[97] Raemakers, C.J.J.M., Sofiari, E., Taylor, N.J., Henshaw, G.G., Jacobsen, E. and Visser. R.G.F. (1996) Production of Transgenic Cassava Plants by Particle Bombardment Using Luciferase Activity as the Selection Marker. Molecular Breeding, 2, 339-349. http://dx.doi.org/10.1007/BF00437912

[98] Schopke, C., Taylor, N.J., Carcamo, R., Konan, N.K., Marmey, P., Henshaw, G.G., Beachy, R.N. and Fauquet, C.M. (1996) Regeneration of Transgenic Cassava Plants (Manihot esculenta Crantz) from Microbombarded Embryogenic Suspension Cultures. Nature Biotechnology, 14, 731-735. http://dx.doi.org/10.1038/nbt0696-731

[99] Siritunga, D. and Sayre, R.T. (2003) Generation of Cyanogen-Free Transgenic Cassava. Planta, 217, 367-373. http://dx.doi.org/10.1007/s00425-003-1005-8

[100] Siritunga, D. and Sayre, R.T. (2004) Engineering Cyanogen Synthesis and Turnover in Cassava (Manihot esculenta). Plant Molecular Biology, 56, 661-669. http://dx.doi.org/10.1007/s11103-004-3415-9

[101] Siritunga, D., Arias-Garzon, D., White, W. and Sayre, R.T. (2004) Over-Expression of Hydroxynitrile Lyase in Transgenic Cassava Roots Accelerates Cyanogenesis and Food Detoxification. Plant Biotechnology Journal, 2, 37-43. http://dx.doi.org/10.1046/j.1467-7652.2003.00047.x

[102] Langridge, W.H.R. (2000) Edible Vaccines. Scientific American, 2000, 66-71.

[103] Pascual, D.W. (2007) Vaccines Are for Dinner. Proceedings of the National Academy of Sciences of the United States of America, 104, 10757-10758. http://dx.doi.org/10.1073/pnas.0704516104

[104] SunilKumar, G.B., Gananpathi, T.R. and Bapat, V.A. (2007) Production of Hepatitis B Surface Antigen in Recombinant Plant Systems. Biotechnology Progress, 23, 523-529.

[105] McGarvey, P.B., Hammond, J., Dienelt, M.M., Hooper, D.C., Fu, Z.F., Dietzschold, B., Koprowski, H. and Michaels, F.H. (1995) Expression of the Rabies Virus Glycoprotein in Transgenic Tomatoes. Bio/Technology, 13, 1484-1487. http://dx.doi.org/10.1038/nbt1295-1484

[106] Ma, Y., Zhang, J., Lin, S.Q. and Xia, N.S. (2001) Genetic Engineering Vaccines Produced by Transgenic Plants. Journal of Xiamen University, 40, 71-77.

[107] Chen, H.F., Chang, M.H., Chiang, B.L. and Jeng, S.T. (2006) Oral Immunization of Mice Using Transgenic Tomato Fruit Expressing VP1 Protein from Enterovirus 71. Vaccine, 24, 2944-2951. http://dx.doi.org/10.1016/j.vaccine.2005.12.047

[108] Benner, G., Andrews, G., Byrne, W., Strachan, S., Sample, A. and Heath, D. (1999) Immune Response to Yersinia Outer Proteins and Other Yersinia pestis Antigens after Experimental Plague Infection in Mice. Infection and Immunity, 67, 1922-1928.

[109] Alvarez, M.L., Pinyerd, H.L., Crisantes, J.D., Rigano, M.M., Pinkhasov, J., Amanda, M., Walmsley, A.M., Masona, H.S. and Cardineau, G.A. (2006) Plant-Made Subunit Vaccine against Pneumonic and Bubonic Plague Is Orally Immunogenic in Mice. Vaccine, 24, 2477-2490. http://dx.doi.org/10.1016/j.vaccine.2005.12.057

[110] Hoheisel, G.A. and Fleischer, S.J. (2007) Coccinelids, Aphids, and Pollen in Diversified Vegetable Fields with Transgenic and Isoline Cultivars. Journal of Insect Science, 7, 1-12. http://dx.doi.org/10.1673/031.007.6101

[111] Leslie, T.W., Hoheisel, G.A., Biddinger, D.J., Rohr, J.R. and Fleisher S.J. (2007) Transgenes Sustain Epigeal Insect Biodiversity in Diversified Vegetable Farm Systems. Environmental Entomology, 36, 234-244. 
http://dx.doi.org/10.1603/0046-225X(2007)36[234:TSEIBI]2.0.CO;2

[112] Krimsky, S. and Wrubel, R.P. (1996) Agricultural Biotechnology and the Environment. University of Illinois Press, Urbana.

[113] Wrubel, R.P. and Gressel, J. (1994) Are Herbicide Mixtures Useful for Delaying the Rapid Evolution of Resistance? A Case Study. Weed Technology, 8, 635-648.

[114] Brookes, G. and Barfoot, P. (2009) GM Crops: Global Socio-Economic and Environmental Impacts 1996-2007. PG Economics, Dorchester.

[115] Ortiz, R. and Smale, M. (2007) Transgenic Crops: Pro-Poor or Pro-Rich? Chronica Horticulturae, 47, 9-12.

[116] FAO (2000) FAO Statement on Biotechnology. Food and Agriculture Organization of the United Nations, Rome. www.fao.org/biotech/stat.asp?lang=en

[117] Royal Society of London, the US National Academy of Sciences, the Brazilian Academy of Sciences, the Chinese Academy of Sciences, the Indian National Science Academy, the Mexican Academy of Sciences and the Third World Academy of Sciences (2000) Transgenic Plants and World Agriculture. National Academies Press, Washington DC.

[118] World Health Organization (2002) 20 Preguntas sobre los alimentos modificados genéticamente. WHO, Geneva. http://www.oei.es/salactsi/20oms.htm

[119] Chassy, B.M. (2002) Food Safety Evaluation of Crops Produced through Biotechnology. Journal of the American College of Nutrition, 21, S166-S173. http://dx.doi.org/10.1080/07315724.2002.10719261

[120] Society of Toxicology (2002) The Safety of Genetically Modified Foods Produced through Biotechnology. Society of Toxicology, Virginia. www.toxicology.org/ai/gm/GM_Food.asp

[121] British Medical Association (2004) Genetically Modified Foods and Health: A Second Interim Statement. British Medical Association, London. http://www.argenbio.org/adc/uploads/pdf/bma.pdf

[122] Union of the German Academies of Science and Humanities (2006) Are There Health Hazards for the Consumers from Eating Genetically Modified Foods? Interacademy Panel Initiative on Genetically Modified Organisms, Berlin. http://www.ilsi.org/NorthAmerica/Documents/UGASH.pdf

[123] Federal Office of Consumer Protection and Food Safety (Germany) and Partners (2009) Long-Term Effects of Genetically Modified (GM) Crops on Health and the Environment (Including Biodiversity): Prioritisation of Potential Risks and Delimitation of Uncertainties. Federal Office of Consumer Protection of Food Safety, Berlin. http://ec.europa.eu/food/food/biotechnology/reports_studies/docs/lt_effects_report_en.pdf

[124] Ortiz, R. (2011) Revisiting the Green Revolution: Seeking Innovations for a Changing World. Chronica Horticulturae, 51, 6-11. http://dx.doi.org/10.1016/j.scienta.2011.09.020

[125] Schouten, H.J., Krens, F.A. and Jacobsen, E. (2006) Cisgenic Plants Are Similar to Traditionally Bred Plants. EMBO Reports, 8, 750-753. http://dx.doi.org/10.1038/sj.embor.7400769

[126] Schouten, H.J., Krens, F.A. and Jacobsen, E. (2006) Do Cisgenic Plants Warrant Less Stringent Oversight? Nature Biotechnology, 24, 753. http://dx.doi.org/10.1038/nbt0706-753

[127] Eriksson, D., Stymne, S. and Schorring, J.K. (2014) The Slippery Slope of Cisgenesis. Nature Biotechnology, $32,727$. http://dx.doi.org/10.1038/nbt.2980

[128] Federoff, N.V. and Brown, N.M. (2004) Mendel in the Kitchen. A Scientist’s View of Genetically Modified Foods. Joseph Henry Press, Washington, DC.

[129] Bradford, K.J., Van Deynze, A., Gutterson, N., Parrott, W. and Strauss, S.H. (2005) Regulating Transgenic Crops Sensibly: Lessons from Plant Breeding, Biotechnology and Genomics. Nature Biotechnology, 23, 439-444. http://dx.doi.org/10.1038/nbt1084 
Scientific Research Publishing (SCIRP) is one of the largest Open Access journal publishers. It is currently publishing more than 200 open access, online, peer-reviewed journals covering a wide range of academic disciplines. SCIRP serves the worldwide academic communities and contributes to the progress and application of science with its publication.

Other selected journals from SCIRP are listed as below. Submit your manuscript to us via either submit@scirp.org or Online Submission Portal.
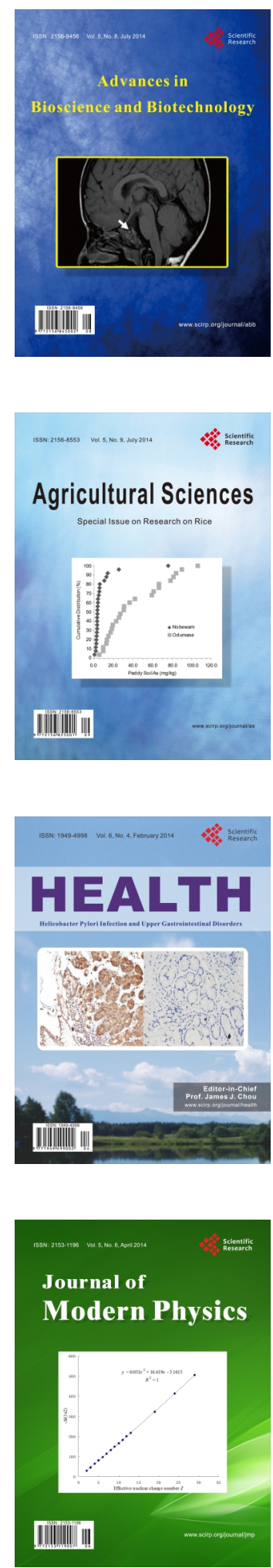
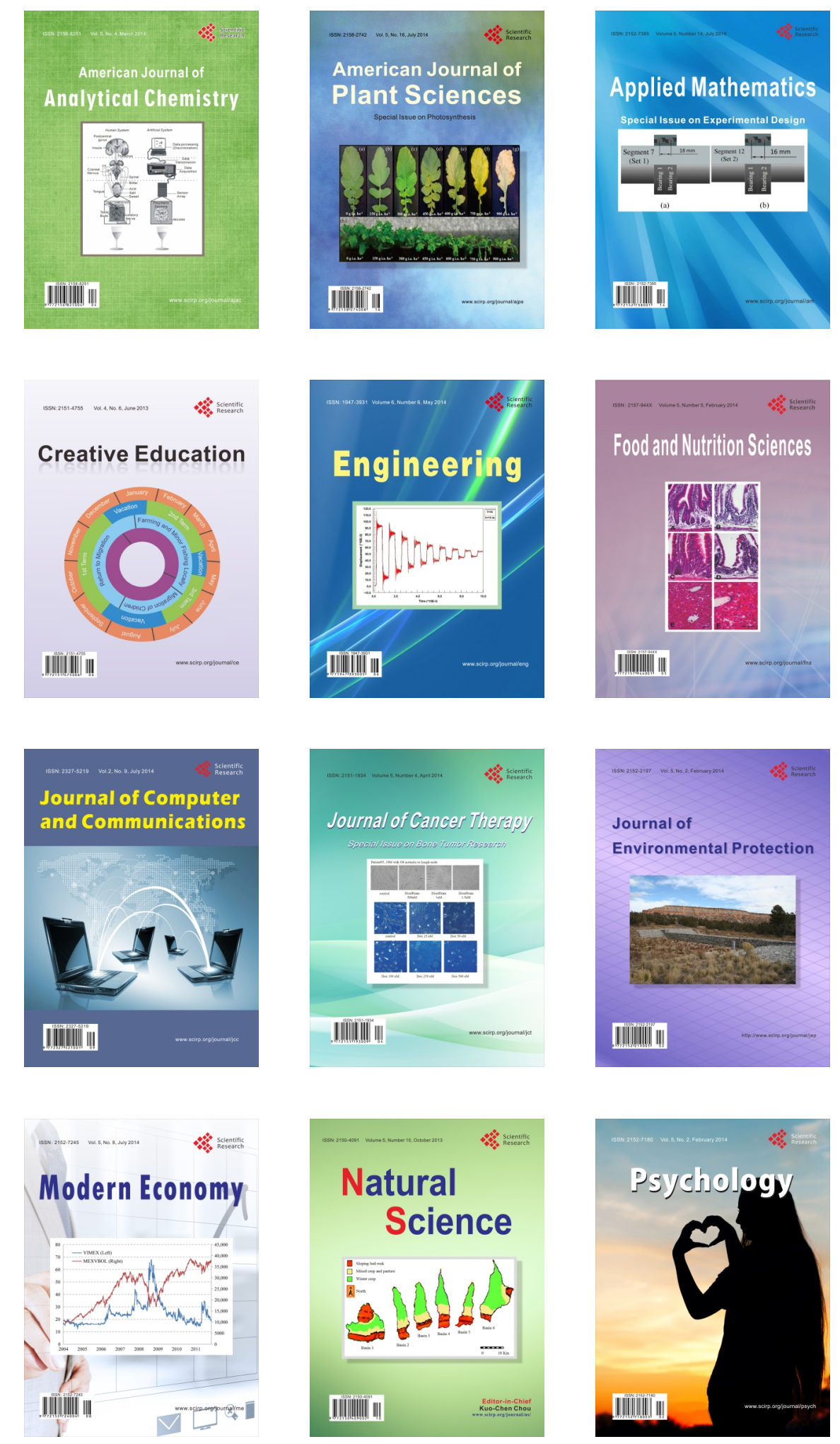